University of Nebraska - Lincoln

DigitalCommons@University of Nebraska - Lincoln

Agronomy \& Horticulture -- Faculty Publications

Agronomy and Horticulture Department

6-18-2008

\title{
Effect of sorghum seedlings, and previous crop, on soil fluorescent Pseudomonas spp.
}

\author{
Deanna L. Funnell \\ University of Nebraska-Lincoln, dfunnell2@unl.edu \\ Jeffrey F. Pedersen \\ University of Nebraska-Lincoln, jpedersen1@unl.edu \\ David B. Marx \\ University of Nebraska-Lincoln, david.marx@unl.edu
}

Follow this and additional works at: https://digitalcommons.unl.edu/agronomyfacpub

Part of the Plant Sciences Commons

Funnell, Deanna L.; Pedersen, Jeffrey F.; and Marx, David B., "Effect of sorghum seedlings, and previous crop, on soil fluorescent Pseudomonas spp." (2008). Agronomy \& Horticulture -- Faculty Publications. 126. https://digitalcommons.unl.edu/agronomyfacpub/126

This Article is brought to you for free and open access by the Agronomy and Horticulture Department at DigitalCommons@University of Nebraska - Lincoln. It has been accepted for inclusion in Agronomy \& Horticulture -Faculty Publications by an authorized administrator of DigitalCommons@University of Nebraska - Lincoln. 


\title{
Effect of sorghum seedlings, and previous crop, on soil fluorescent Pseudomonas spp.
}

\author{
Deanna L. Funnell-Harris • Jeffrey F. Pedersen • \\ David B. Marx
}

Received: 26 December 2007 / Accepted: 26 May 2008

\begin{abstract}
Hypotheses in which sorghum seedlings [Sorghum bicolor (L.) Moench] of different genotypes will differentially modify soil microorganisms and will affect subsequent planting of wheat (Triticum aestivum L.) seedlings, were tested. Wheat cultivar Lewjain, and sorghum genotypes Redlan and RTx433, were planted into soils previously planted with wheat or sorghum in growth chamber experiments. Total culturable fungi and oomycetes, and fluorescent Pseudomonas spp. numbers (cfu) were
\end{abstract}

Responsible Editor: Peter A.H. Bakker.

D. L. Funnell-Harris $(\bowtie)$

USDA-ARS, Grain, Forage and Bioenergy Research, University of Nebraska, Department of Plant Pathology,

314 Biochemistry Hall, UNL-East Campus,

Lincoln, NE 68583-0737, USA

e-mail: Deanna.Funnell-Harris@ars.usda.gov

J. F. Pedersen

USDA-ARS, Grain, Forage and Bioenergy Research,

University of Nebraska,

Department of Agronomy and Horticulture,

314 Biochemistry Hall, UNL-East Campus,

Lincoln, NE 68583-0737, USA

D. B. Marx

Department of Statistics,

University of Nebraska,

340 Hardin Hall, UNL-East Campus,

Lincoln, NE 68583-0963, USA determined. Pseudomonads were screened for hydrogen cyanide $(\mathrm{HCN})$ production, for the presence of the phlD gene for 2,4-diacetylphloroglucinol production $(\mathrm{Phl})$ and for a region of the operon involved in phenazine-1-carboxylic acid (PCA) production. Pasteurized soils were inoculated with rifampicin-marked strains of Pseudomonas fluorescens then planted with Lewjain, Redlan and RTx433 to assess rhizosphere and soil colonization. Effects of plant species, sorghum genotype and previous crop on culturable fungi and oomycetes, and pseudomonad numbers (cfu $\mathrm{g}^{-1}$ soil) were statistically significant. Soils planted with RTx433 or Lewjain had greater numbers of fungal cfu than soils planted with Redlan. When Lewjain seedlings were grown in soil previously planted with RTx433, there were greater numbers of fungal cfu than when Lewjain was planted into Redlan soil. Wheat planted into wheat soil resulted in statistically significantly fewer numbers of pseudomonads than when planted into sorghum soil. Overall, percentages of HCN-producing pseudomonads increased, especially when wheat seedlings were planted in wheat soil. For most treatments, percent of isolates with $P h l$ declined, except when Redlan was planted into Redlan soil, which resulted in increased $P h l$ isolates. When rifampicin-marked P. fluorescens isolates were applied to pasteurized soil, sorghum seedlings sustained rhizosphere and soil populations similar to those on wheat. Sorghum genotypes may differ in associations with soil microorganisms, 
suggesting that they may differentially affect numbers of fluorescent pseudomonads in cropping systems.

Keywords 2, 4-Diacetylphloroglucinol · Cycling • Pseudomonas fluorescens $\cdot$ Sorghum bicolor (L.) Moench · Sorgoleone - Triticum aestivum L.

\author{
Abbreviations \\ Phl 2,4-diacetlyphloroglucinol \\ PCA phenazine-1-carboxylic acid \\ TSA tryptic soy agar
}

\section{Introduction}

Fluorescent Pseudomonas spp. on plant root surfaces and in soil closely associated with roots may contribute to natural protection of plants against root pathogens (Loper et al. 2007; Mercado-Blanco and Bakker 2007). This protection may be accomplished, at least in part, by production of antagonistic proteins, such as proteases, and bactericidal compounds, such as hydrogen cyanide (HCN) and antibiotics (Duffy et al. 2004; Loper et al. 2007). Efficacy of microorganisms that may contribute to plant health may be dependent on soil qualities, environment and cultural management (McSpadden-Gardener 2007).

Genotypes of wheat or sorghum can produce differential amounts and types of secondary metabolites in root exudates (Bertin et al. 2003). Of particular interest have been potentially allelopathic compounds that may inhibit growth of weeds (Belz 2007), but also have been implicated in allelopathic interactions with crop plants (Roth et al. 1999; Wu et al. 2007). Besides effects on plants, allelochemicals may be involved in modifications of physical properties of soil or activities of soil microorganisms (Bertin et al. 2003). Wheat root exudates that may have allelopathic potential are phenolic compounds (Wu et al. 2001). The major group of root exudates from sorghum with allelopathic properties is the benzoquinonones called sorgoleone $\{2$-hydroxy-5-methoxy-e-[(8Z,11Z8,11,14-pentadecatriene]-p-benzoquinone \} (Chang et al. 1986; Belz 2007). Production of allelopathic phenolics by wheat seedling roots grown on agar medium have been shown to vary by types and levels, depending upon the cultivar (Wu et al. 2001). Sorgoleone production levels by sorghum seedlings grown in germination chambers also have been shown to be genotype-specific (Nimbal et al. 1996).

Types and quantities of root exudates can affect microbial activity in the rhizosphere and adjacent soil in a species-specific manner (Weiland et al. 2001; Fageria and Stone 2006). Differences between numbers of microorganisms and genetic differences among populations of fluorescent Pseudomonas spp. are discernible among wheat cultivars (Gu and Mazzola 2003; Mazzola and $\mathrm{Gu}$ 2002). It is likely that modifications in populations of beneficial Pseudomonas spp. can positively affect the growth of plantings following wheat (Mazzola and $\mathrm{Gu} 2000$ ) or during wheat monoculture (Cook et al. 1995; Raaijmakers and Weller 1998).

Antibiosis is a trait involved in protection of plants by fluorescent Pseudomonas spp. (Raaijmakers and Weller 1998). Extracellular proteins produced by these bacteria, such as proteases, and extracellular metabolites, such as hydrogen cyanide (HCN), 2,4-diacetlyphloroglucinol (Phl) and phenazine-1-carboxylic acid (PCA), can inhibit growth of fungal pathogens in vitro (Mazzola et al. 1995; Berg et al. 2002; Bano and Musarrat 2003), and have been implicated as contributing to biological control capabilities by fluorescent Pseudomonas spp. (Cook et al. 1995; Rezzonico et al. 2007). Previous results have indicated that sorghum roots can support populations of fluorescent Pseudomonas spp. (Andrade et al. 1998).

It has been previously reported that sorghum can negatively impact wheat in rotation systems (Roth et al. 1999). Because wheat and sorghum can be grown in succession in the Great Plains (Schlegel et al. 2002), it was of interest to examine possible direct or indirect affects of sorghum genotypes on wheat seedlings and on microbial populations. The following three hypotheses were tested. (1) Sorghum seedlings will inhibit growth of subsequently planted wheat seedlings. (2) Sorghum seedlings of different genotypes modify soil and rhizosphere populations of microorganisms differentially. (3) Sorghum rhizospheres can sustain populations of fluorescent Pseudomonas spp. at a level similar to wheat.

\section{Materials and methods}

Plant materials and bacterial isolates

Sorghum [Sorghum bicolor (L.) Moench] genotypes Redlan and RTx433 were chosen because, in a 
previous study, cultivar Redlan produced high levels of sorgoleone in germination chamber assays while RTx433 produced low levels (Nimbal et al. 1996). Sorghum seed were produced at University of Nebraska Field Laboratories (UNL), Ithaca, NE. Wheat (Triticum aestivum L.) cultivar Lewjain was used as a positive control for induction of growth of Phl-producing fluorescent Pseudomonas spp. (Mazzola et al. 2004). Lewjain seed was obtained from K. Garland-Campbell (USDA-ARS, Pullman, WA). P. fluorescens isolates Q2-87 and Q8r1-96, and their spontaneous rifampicin derivatives $\left(\mathrm{Q} 2-87 \mathrm{R}^{+}\right.$and Q8r1-96 $\mathrm{R}^{+}$), were obtained from M. Mazzola (USDAARS, Wenatchee, WA) and L. Thomashow (USDAARS, Pullman, WA), respectively, (Raaijmakers and Weller 2001), and isolate 2-79 (Mavrodi et al. 1998) also was obtained from L. Thomashow. P. fluorescens isolate NRRL B-23932 was obtained from USDAARS, National Center for Agricultural Utilization Research (NCAUR), Peoria, IL. Wild type isolates were maintained in culture on Kings $B(\mathrm{~KB})$ agar (Cowan 1974) and mutants on KB agar amended with rifampicin (100 $\mu \mathrm{g} \mathrm{ml}^{-1}$; Sigma-Aldrich, St. Louis, MO, USA). Bacteria were stored at $-80^{\circ} \mathrm{C}$ in $0.44 \%$ nutrient broth, $0.08 \%$ yeast extract [(Becton, Dickinson and Co. (BD), Sparks, MO USA)], 0.02\% glucose and $45 \%$ glycerol.

Media for enumeration of fungi and bacteria

Approximately $1 \mathrm{~g}$ of soil was suspended into $10 \mathrm{ml}$ of sterile purified water (Labconco, Kansas City, MO, USA). Total bacterial colony forming units (cfu) per gram was estimated by plating dilutions $\left(1 \times 10^{-5}, 1 \times\right.$ $10^{-6}$ and $1 \times 10^{-7}$ ) of this suspension onto one-tenth strength tryptic soy agar [TSA; prepared with tryptic soy broth (BD)]. To estimate total culturable fungal and oomycete cfu per gram of soil, the diluted suspension $\left(1 \times 10^{-3}, 1 \times 10^{-4}\right.$ and $\left.1 \times 10^{-5}\right)$ was plated onto one fifth strength potato dextrose agar [PDA; prepared with potato dextrose broth (BD)] amended with $0.04 \%$ Triton X-100 (Calbiochem, EMD Biosciences, San Diego) and $50 \mu \mathrm{g} \mathrm{ml} \mathrm{m}^{-1}$ ampicillin. Fluorescent Pseudomonas spp. were isolated by plating dilutions of the soil suspension $\left(1 \times 10^{-2}, 1 \times\right.$ $10^{-3}$ and $1 \times 10^{-4}$ ) onto $\mathrm{KB}$ amended with ampicillin (100 $\left.\mu \mathrm{g} \mathrm{ml}^{-1}\right)$, cycloheximide $\left(100 \mu \mathrm{g} \mathrm{ml}^{-1}\right)$ and chloramphenicol $\left(13 \mu \mathrm{g} \mathrm{ml}^{-1}\right.$; $\mathrm{KB}^{+}$; Simon and Ridge 1974). Following examination under ultraviolet light, fluorescing colonies were transferred to $\mathrm{KB}$ agar and, after growth of colonies, fluorescence was confirmed. For selection of antibiotic mutants, either roots $(0.5$ to 1 $\mathrm{g}$ ) or soil (approximately $1 \mathrm{~g}$ ) were suspended in ten $\mathrm{ml}$ sterile purified water. Dilutions $\left(1 \times 10^{-4}, 1 \times 10^{-5}\right.$ and $1 \times 10^{-6}$ ) from soil or root suspensions were plated onto $\mathrm{KB}^{+}$agar containing rifampicin $\left(100 \mu \mathrm{g} \mathrm{ml}^{-1}\right)$. Antibiotics were purchased from Sigma-Aldrich.

Preparation of conetainers

Soil was obtained from a non-irrigated sorghum field at UNL, Lincoln. Soil at this location is a Kennebec silt loam, a fine-silty, mixed, superactive, mesic Cumulic Hapladoll. Conetainers, $4 \mathrm{~cm}$ diameter by $22.5 \mathrm{~cm}$ long, were filled with soil and seeds of wheat cultivar Lewjain or of sorghum genotypes Redlan or RTx433 were sown onto the soil surface and covered with soil then vermiculite. Each cone was watered with 10 to $15 \mathrm{ml}$ of sterilized one third strength Hoaglund's solution lacking minerals (M. Mazzola, personal communication) prepared with filter-distilled water then watered three times per week with sterile filter-distilled water. After germination, seedlings were culled to one plant per conetainer and maintained in a growth chamber at $22^{\circ} \mathrm{C}$ with $12 \mathrm{~h}$ light.

Wheat and sorghum seedling cycling

Field soils used for cycling were from sites with 2-year sorghum-soybean rotations that had been planted in sorghum prior to collection. Freshly collected soils were assessed for total numbers of culturable fungi and bacteria and numbers of fluorescent Pseudomonas spp. per gram soil using dilution plating before planting the experiments. Four planting cycles were done in the following manner. For cycle 1,84 conetainers of wheat cultivar Lewjain and 56 conetainers of each sorghum genotype, Redlan or RTx433, were planted (Fig. 1a). Rows of seven cones of each species or line were alternated in racks. To assess growth of seedlings through cycling, at the end of 4 weeks, stalks and leaves were removed at soil level and total wet weight of aerial parts in each row (i.e. seven plants) was determined. Soil from all conetainers of either wheat, or of the two sorghum genotypes were combined in surface-sterilized tubs and the root masses were gently distributed through the soil. To determine whether soil microorganism 
Fig. 1 Diagrams of growth chamber cycling. Four-week plantings of seedlings of each species and genotype were conducted for a total of four cycles. At the end of each cycle, wet weight of above ground plant parts was determined. Three soil samples were taken and analyzed for numbers of culturable bacteria, numbers of culturable fungi and oomycetes, and numbers of fluorescent Pseudomonas spp. per gram soil. a Cycling of wheat and sorghum seedlings in field soil. Wheat cultivar Lewjain $(L)$ or sorghum genotypes Redlan $(R)$ or RTx433 (T) were planted in conetainers (one plant per conetainer). Seedlings were grown for four weeks then, after removal of above-ground plant parts, roots and soil from conetainers planted with one of the three plants were mixed and returned to the same conetainers (one cycle). This was repeated for a total of four cycles, labeled 1,2,3 and 4. Comparisons were made between soils planted with wheat cultivar Lewjain, sorghum cultivar Redlan and sorghum genotype RTx433. b Cycling of wheat and sorghum seedlings in soil previously planted with the alternate crop. Soil previously planted with Lewjain soil $(L)$ was planted with either Lewjain or with one of two sorghum genotypes. Soils previously planted with each sorghum genotype $[(R)$ for Redlan and $(T)$ for RTx433] were planted either with the same sorghum genotype or with Lewjain. After 4 weeks, above-ground plant parts from conetainers with the same treatment were removed and the contents of conetainers (roots and soil) were mixed and returned to the same conetainers. Cycles were repeated for a total of four cycles. To distinguish this experiment from cycling in field soil, the cycles were labeled 5, 6, 7 and 8. Comparisons were made with the same plant grown in different soils. Plant species and genotype cycled in soil previously cropped to the same species and genotype were considered controls

populations ( $\mathrm{cfu} \mathrm{g}^{-1}$ ) were effected by plant genotype, culturable fungi and oomycetes, bacteria and fluorescent Pseudomonas spp. were enumerated by dilution plating of three approximately $1 \mathrm{~g}$ soil samples as described above. Soil containing wheat roots was dispensed into the 84 conetainers previously planted with wheat and soils containing roots of each sorghum genotype were dispensed into the same 56 conetainers previously planted with each genotype. The soils were then replanted with the same species and genotype. This constituted the beginning of cycle 2 and steps were repeated such that plantings of each species and genotype occurred four times in the same soil for four cycles. To limit contamination from outsides sources, or cross-contamination between samples, plants were watered with sterile purified water using sterile pipettes. When processing plant materials, personnel wore gloves which were discarded between samples and instruments were surface sterilized between samples.

The experiment was repeated twice. Wet weight of above-ground plant parts, and numbers of each type a Cycling in field soilCycles 1 through 4
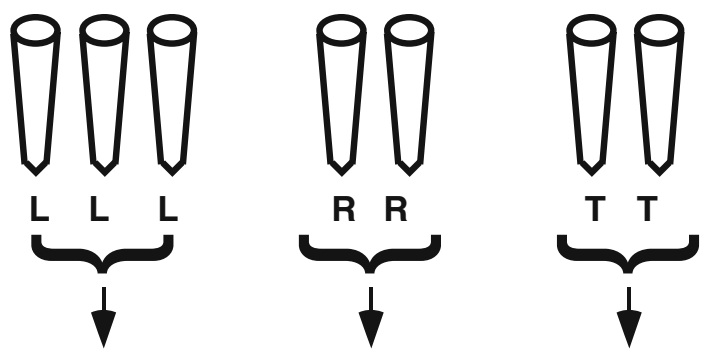

\section{b Cycling in soil previously planted with wheat or sorghum seedlings-} Cycles 5 through 8
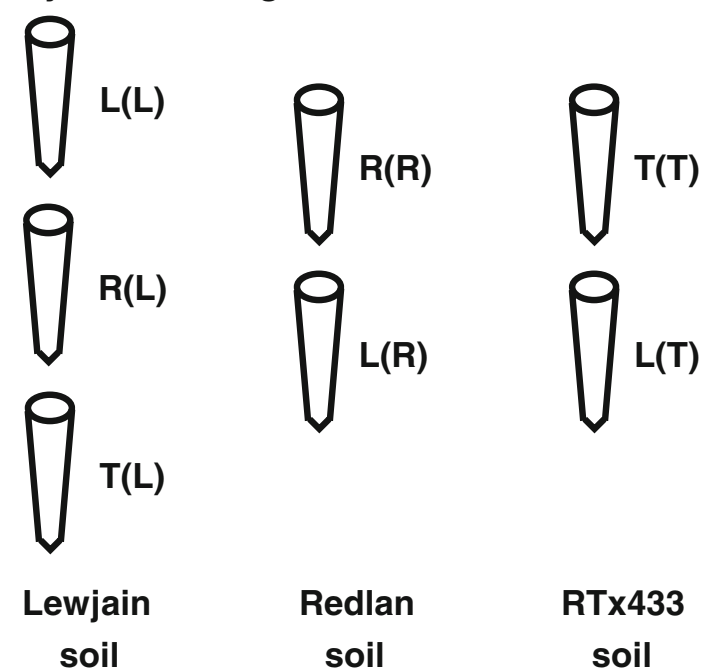

T(L)

\section{Comparisons:}

\section{$L(L)$ versus $L(R)$ versus $L(T)$ $R(R)$ versus $R(L)$ $\mathrm{T}(\mathrm{T})$ versus $\mathrm{T}(\mathrm{L})$}

of microorganism were compared by plant genotype (Fig. 1a). For analyses of plant wet weights, the experimental unit was the row for each plant genotype and cycle (12 repetitions for wheat and eight repetitions for each sorghum genotype). For analyses of microorganisms, the experimental unit was the tub of soil, which was sub-sampled thrice per plant genotype and cycle, and the replicates were the experiments. In figures, results and discussion, the four cycles of this experiment were referred to as 1,2 , 3 and 4 (Fig. 1a). 
Cycling in soil previously planted with wheat or sorghum seedlings

To test effects of previous crop on seedling growth and on soil microorganism populations, an experiment was planted in soils developed from the previously described experiment. Soils were labeled L for wheat cultivar Lewjain, $\mathrm{R}$ for sorghum cultivar Redlan and T for sorghum genotype RTx433 (Fig. 1b). Cycle 5 was conducted in the following way. Twentyeight conetainers filled with $L$ soil were planted with either sorghum cultivar Redlan or sorghum genotype RTx433 as described above, and 28 conetainers containing $\mathrm{R}$ soil and 28 conetainers with $\mathrm{T}$ soil were planted with Lewjain. As controls, 28 conetainers with L soil were planted with Lewjain, 28 conetainers containing $\mathrm{R}$ soil were planted with Redlan and 28 conetainers of $\mathrm{T}$ soil were planted with RTx433 (Fig. 1b). After 4 weeks, above-ground plant parts were removed and wet weight was determined, and soils from conetainers planted with the same genotype were combined, sampled and redistributed into the same conetainers, as described above. Conetainers were then replanted with the same species and genotype, which was the beginning of cycle 6. Steps were repeated such that plantings of each species and genotype occurred four times in the same soil for four cycles. Efforts to limit contamination from outside sources, or cross-contamination between samples were made, as described above.

The experiment was repeated twice. Wet weight of above ground plant parts and numbers of each microorganism in soil were compared by plant genotype (Fig. 1b). For analyses of plant wet weights, the experimental unit was the row for each treatment and cycle (four repetitions per treatment). For analyses of microorganisms, the experimental unit was the tub of soil, which was sub-sampled thrice per plant genotype and cycle, and the replicates were the experiments. To distinguish from cycles in the previous experiment, these cycles were referred to as $5,6,7$ and 8 in figures, results and discussion.

\section{Characterization of fluorescent Pseudomonas spp.}

To determine whether fluorescent Pseudomonas spp. colonizing soils varied depending on sorghum genotype, a subset of isolates was characterized for extracellular protease production, production of ex- tracellular $\mathrm{HCN}$ and for the presence of genes in the $P h l$ and $P C A$ loci. Extracellular protease activity was determined on $2 \%$ skim milk agar (BD). Production of $\mathrm{HCN}$ was determined by a modification of a colorimetric agar plate method (Castric and Castric 1983). Fresh cultures of each isolate were prepared by inoculating KB agar and incubating for 48 to $72 \mathrm{~h}$. at room temperature. Petri dishes $(100 \mathrm{~mm})$ were prepared with two layers of $2 \%$ peptone agar (BD), the bottom layer containing $2 \%$ agar and the top layer, $1.5 \%$ agar. Depressions in the agar (12 to 24$)$, created by removing the top agar layer (Ibid.), were inoculated with 10 to 22 unknown bacterial isolates and twice with isolate NRRL B-23932, positive for $\mathrm{HCN}$ production. Three nylon mesh circles were stacked onto the agar surface. Chromatography paper (3 mm; Whatman, Maidstone, GB) was freshly prepared by soaking in detection reagent (Ibid.) and dried before laying atop the mesh circles. Air bubbles were removed with a glass spreader then two size 1 flat washers (Hillman Fastener, Cincinnati, OH, USA) were gently placed on the paper to keep it in place. Petri plates thusly prepared were incubated at $35^{\circ} \mathrm{C}$ for 3 to $3.5 \mathrm{~h}$ then scored.

To detect the presence of $P h l$, PCR amplification of phlD was conducted (Bangera and Thomashow 1999), while the presence of $P C A$ was detected using primer sequences from within the $p h z C$ and $p h z D$ genes (Raaijmakers et al. 1997; Mavrodi et al. 1998). DNAs from individual bacterial isolates were prepared and diluted as previously described (Mazzola and $\mathrm{Gu}$ 2002). Amplifications were conducted using primers Phl2a and Phl2b for $P h l$ and PCA2a and PCA3b for PCA (Raaijmakers et al. 1997). Reactions were $25 \mu \mathrm{l}$ volumes including $1.5 \mathrm{mM} \mathrm{MgCl}_{2}$ and 2.0 to $2.5 \mathrm{U}$ of Amplitaq Gold [Applied Biosystems (AB), Foster City, CA USA] (Raaijmakers et al. 1997; Mazzola et al. 2004). Amplifications were conducted on Gene Amp ${ }^{\circledR}$ PCR System 9700 (AB). Conditions for amplifying $P h l$ consisted of a hot start cycle at $94^{\circ} \mathrm{C}$ for $2 \mathrm{~min}$, then 30 cycles at $94^{\circ} \mathrm{C}$ for $1 \mathrm{~min}$, $57^{\circ} \mathrm{C}$ for $45 \mathrm{~s}$ and $72^{\circ} \mathrm{C}$ for $1 \mathrm{~min}$, followed by an extension cycle at $72^{\circ} \mathrm{C}$ for $7 \mathrm{~min}$. Amplifications of the PCA region were conducted as previously reported (Raaijmakers et al. 1997). DNA templates extracted from isolates Q2-87 and 2-79 served as positive controls for $P h l$ and $P C A$, respectively (Mavrodi et al. 1998; Bangera and Thomashow 1999). Amplification products were size-fractionated 
by electrophoreses on $1 \%$ agarose gels, then visualized by treatment with ethidium bromide solution (Bio-Rad, Laboratories, Inc., Hercules, CA USA).

Survival of Phl-producing isolates on roots and soil of wheat and two sorghum genotypes

In order to test whether sorghum genotypes RTx 433 and Redlan can sustain root and soil populations of well-characterized wheat isolates of $P$. fluorescens under controlled conditions, pasteurized soils were applied with $1 \times 10^{8} \mathrm{cfu} \mathrm{g}^{-1}$ of either Q2-87R $\mathrm{R}^{+}$and Q8r1-96R ${ }^{+}$, marked with rifampicin resistance. Soil was obtained from a non-irrigated sorghum field at UNL, Lincoln, that had previously been planted with soybean. Isolate Q2-87R $\mathrm{R}^{+}$or Q8r1-96 $\mathrm{R}^{+}$was grown in one twentieth strength $\mathrm{KB}$ broth amended with ampicillin $\left(50 \mu \mathrm{g} \mathrm{ml}^{-1}\right)$ overnight at $22^{\circ} \mathrm{C}$ to $25^{\circ} \mathrm{C}$. Cells were collected by centrifugation and washed twice with sterile purified water then diluted so that when applied to soil approximately $1 \times 10^{8} \mathrm{cfu} \mathrm{g}^{-1}$ of soil was attained. Concentration of suspension $\left(1 \times 10^{9}\right.$ to $1 \times 10^{10} \mathrm{cfu} \mathrm{ml} \mathrm{m}^{-1}$, suspended in $150 \mathrm{ml}$ sterile purified water) depended on total weight of pasteurized soil. Ten $\mathrm{ml}$ aliquots of cells were sprayed onto pasteurized soil using a chromatography sprayer then soil was thoroughly mixed after each aliquot. Concentrations of rifampicin-resistant bacteria in suspension $\left(\mathrm{cfu} \mathrm{ml}^{-1}\right)$ and of freshly prepared soil $\left(\mathrm{cfu} \mathrm{g}^{-1}\right)$ were confirmed by dilution plating onto $\mathrm{KB}^{+}$ amended with rifampicin. Treated soil was dispensed into conetainers and 28 or 42 were planted with seed of either wheat cultivar Lewjain or of sorghum genotypes Redlan or RTx433 as described above. Rows of each species or genotype were alternated and plants were cultivated and maintained as described above. Two weeks following planting and weekly thereafter, roots ( 0.5 to $1 \mathrm{~g}$ ) or soil (approximately $1 \mathrm{~g}$ ) from seven randomly chosen plants of wheat and of each sorghum genotype were suspended in $10 \mathrm{ml}$ sterile purified water. Suspensions were diluted $(1 \times$ $10^{-5}, 1 \times 10^{-6}$ and $1 \times 10^{-7}$ for roots and $1 \times 10^{-4}, 1 \times$ $10^{-5}$ and $1 \times 10^{-6}$ for soil) and plated onto $\mathrm{KB}^{+}$plates amended with rifampicin, as previously described. Colonies were counted to determine rifampicinresistant bacterial cfu per gram of root tissue or of soil. Comparisons were made between bacterial numbers on roots or soil for each plant genotype at each time point. The experimental unit was one conetainer (one plant) and seven containers were assessed for each genotype and each time point. The experiments were conducted twice with each $P$. fluorescens isolate.

Statistical analyses

Response variables for wheat and sorghum genotype cycling were analyzed using SAS ${ }^{\circledR}$ Proc Mixed software (SAS 2000-2004) with the Prasad-RaoJeske-Kackar-Harville option to estimate fixed effects and the Kenward-Roger option for estimating degrees of freedom. For wheat and sorghum cycling, comparisons were between different plant genotypes and between cycles of a genotype. When considering previous crop effects, comparisons were made between soils for a given genotype and cycle using the same Proc Mixed procedure and options.

For numbers of total bacteria, total fungi or fluorescent Pseudomonas spp., no colonies were recovered for some treatment combinations. In these cases the value used as the data point in the analyses was level of detection minus one. A Shapiro-Wilks test (SAS) was conducted for normality and the data for each of the above response variables were determined to not be normally distributed $(P<0.01)$. Therefore, numbers were transformed into natural $\operatorname{logs}(\ln )$ and transformed numbers were analyzed. For ease of reading results, means and standard errors in ln were back-transformed using Proc Glimmix and numeric means and standard errors (SE) were reported in text. Means and standard errors in $\ln$ were used in preparing histograms. Differences were considered significant when $P \leq 0.05$.

For comparisons of percentages of fluorescent Pseudomonas spp. with each antibiotic activity, treatments and time points in which no fluorescent pseudomonads were recovered, the percentage of each antibiotic activity was considered " 0 ." Proc GLM (SAS) was conducted using percentages. Numeric means and standard deviations (SD) were reported.

For trials with rifampicin-marked P. fluorescens isolates, assays were analyzed separately. The ShapiroWilks test (SAS) was conducted for normality and the data for all assays were determined to be not normally distributed $(P<0.01)$. Therefore, numbers were transformed into natural logs. Due to subtle differences in the data set as compared to the above, analyses were 
conducted using Proc Mixed with model-based fixed effects, and use of containment for estimating degrees of freedom. For numbers of microorganisms, which were transformed into ln for analyses, numeric means and SE are reported in text and in the table for ease of reading results.

\section{Results}

Wheat and sorghum seedling cycling

Four 4-week cycles of wheat cultivar Lewjain and sorghum genotypes RTx433 and Redlan were planted (Fig. 1a). Mean total weights were significant for plant $\times$ cycle effects $(P<0.01)$. However, when comparing mean weights for a given plant genotype at different cycles, there were no significant differences.

When comparing numbers of bacteria in soil prior to planting and after the first cycle, there were no significant differences in numbers of culturable bacteria per gram. During cycling there were no significant differences when considering genotype, cycle or genotype $\times$ cycle interactions. Means across all cycles for bacteria per gram soil ranged from $2.52 \times 10^{7}(\mathrm{SE}=$ $\left.2.90 \times 10^{6}\right)$ to $3.63 \times 10^{7}\left(\mathrm{SE}=4.23 \times 10^{6}\right)$.

There were no significant differences in mean numbers of culturable fungi and oomycetes per gram of soil when comparing preplant soil and after cycle 1 of planted soils (Fig. 2a; preplant soil mean is indicated with asterisk). During cycling, mean numbers of fungal and oomycete cfu per gram soil increased with each cycle ( $P=0.04$; Fig. 2a). Means of cfu per gram soil for each genotype across cycles also were significantly different $(P<0.01)$. Soils planted with wheat cultivar Lewjain $\left(4.05 \times 10^{5} ; \mathrm{SE}=5.19 \times 10^{4}\right)$ or sorghum genotype RTx433 $\left(3.77 \times 10^{5} ; \mathrm{SE}=4.62 \times 10^{4}\right)$ had significantly greater fungal and oomycete cfu per gram than soil planted with sorghum cultivar Redlan $\left(1.88 \times 10^{5} ; \mathrm{SE}=2.37 \times 10^{4}\right)$. Figure $2 \mathrm{a}$ illustrates the number of culturable fungi and oomycetes per gram soil associated with soil of each genotype at each cycle.

There were no significant differences between cfu per gram soil of fluorescent Pseudomonas spp. prior to planting and one cycle after planting $(P=0.08$; Fig. 2b; preplant soil mean is indicated with asterisk). During cycling, mean numbers of fluorescent Pseudomonas spp. were statistically significant for plant genotype

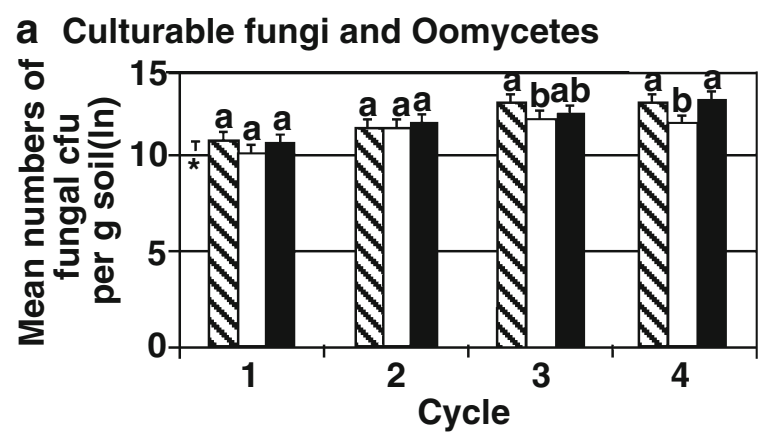

b Fluorescent Pseudomonas spp.

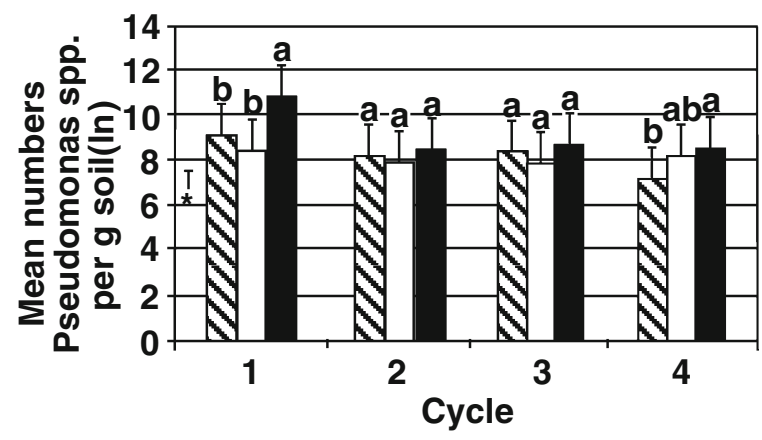

Genotype: $\nabla$ Lewjain $\square$ Redlan $\square$ RTx433

Fig. 2 Ln of mean numbers of cfu per gram soil of culturable fungi and Oomycetes (a) or fluorescent Pseudomonas spp. (b) at end of each cycle planted with seedlings of wheat cultivar Lewjain and sorghum genotypes Redlan and RTx433. Soil was obtained from sorghum fields. Positive SEs are shown. Comparisons between lines within each cycle are indicated with letters; the same letter indicates there were no significant differences between lines. Asterisks on left sides of histograms indicate $\ln$ of mean numbers of cfu per gram soil prior to planting

across cycles $(P=0.02$; Fig. $2 b)$. Mean numbers of fluorescent Pseudomonas spp. per gram soil associated with sorghum genotype RTx433 $\left(1.38 \times 10^{4}\right.$; $\mathrm{SE}=2.70 \times 10^{3}$ ) was significantly greater than those found in soil planted with wheat cultivar Lewjain $\left(9.26 \times 10^{3} ; \mathrm{SE}=1.99 \times 10^{3}\right)$ or with sorghum cultivar Redlan $\left(5.37 \times 10^{3} ; \mathrm{SE}=1.12 \times 10^{3}\right.$; Fig. $\left.2 \mathrm{~b}\right)$. Cycle or genotype $\times$ cycle interactions were not significant. Figure $2 \mathrm{~b}$ illustrates numbers of fluorescent Pseudomonas spp. associated with each genotype during cycling.

Cycling in soils previously planted with wheat or sorghum seedlings

Four 4-week cycles of wheat cultivar Lewjain and sorghum genotypes RTx433 and Redlan were planted 
into soils previously planted with either wheat or sorghum (Fig. 1b). When cycling in soils previously planted with either wheat or two sorghum genotypes, there were statistically significant differences in mean total weights for plant genotype $\times$ cycle interactions $(P=0.01)$; however, there were no biologically relevant differences when considering mean weights of a given genotype grown in different soils or when comparing mean weights of the same treatment in different cycles.

When comparing mean numbers of culturable bacteria per gram soil for the same plant grown in different soils, there were statistically significant differences attributable to treatment $(P=0.03)$ across all cycles following rotation. There were significantly greater numbers of bacteria per gram of soil from cycling wheat seedlings in soil previously planted with wheat or with sorghum cultivar Redlan $\left[6.6610^{7}\right.$ $\left(\mathrm{SE}=8.51 \times 10^{6}\right)$ and $8.49 \times 10^{7}\left(\mathrm{SE}=1.17 \times 10^{7}\right)$, respectively], than when wheat seedlings were cycled in soil previously planted with sorghum genotype RTx433 $\left(4.00 \times 10^{7} ; \mathrm{SE}=5.15 \times 10^{6}\right)$. There were no significant differences in mean numbers of bacteria attributable to cycle or to treatment $\times$ cycle interactions.

For numbers of culturable fungi and oomycetes per gram soil, statistically significant effects attributable to previous crop, means across all cycles, were apparent $(P=0.02)$. Interactions between cycles and genotypes planted in different soils also were significant $(P<0.01)$. Mean fungal and oomycete cfu between treatments were significant for cycles 5,6 and 7 (Fig. 3a). Mean fungal and oomycete cfu per gram soil for wheat cultivar Lewjain planted into soil previously planted with sorghum genotype RTx433 was significantly higher than when Lewjain seedlings were planted into soil previously planted with sorghum cultivar Redlan for cycles 5 and $6(P=0.02$ and 0.03 respectively; Fig. 3a). Also, mean fungal and oomycete cfu of soil associated with RTx433 seedlings cycled in RTx433 soil were higher than when RTx433 seedlings were planted into soil previously planted with wheat cultivar Lewjain in cycles 6,7 and 8 and significantly higher in cycle 7 ( $P<0.01$; Fig. $3 \mathrm{a})$.

Mean numbers of fluorescent Pseudomonas spp. per gram soil were statistically significant when considering treatment and treatment $\times$ cycle interactions $(P<0.01$; Fig. 3b). Comparisons of biologically relevant treatments within cycles showed that in cycle 8 mean numbers of fluorescent Pseudomonas spp. per gram soil associated with planting of wheat cultivar Lewjain were significantly different for previously planted crop. When wheat seedlings were planted into soils previously planted with sorghum seedlings, mean numbers of fluorescent Pseudomonas spp. were significantly greater than when wheat was planted into soil previously planted with wheat (Fig. 3b).

Characteristics of fluorescent Pseudomonas spp. associated with seedlings of wheat and two sorghum genotypes, taking into consideration previous crop

Fluorescent Pseudomonas spp. were isolated from sorghum field soil following harvest or winter fallow but prior to planting the experiment. When screened for four characteristics (HCN production, protease activity or the presence of $P h l$ or $P C A$ ), only protease activity was detected (Table 1). After cycle 1, Pseudomonas isolates with the ability to produce $\mathrm{HCN}$ were detected in soils planted with the three genotypes [Lewjain, 2.5\% ( $\mathrm{SD}=3.5)$; Redlan, 25.0\% $(\mathrm{SD}=35.4)$; RTx433, 12.5\% (SD=17.7)] The $P h l$ locus also was detected in isolates from soil planted with Lewjain $(55.9 \%$; $\mathrm{SD}=55.4)$ and with $\mathrm{RTx} 433$ (9.1\%; SD=12.9) after cycle $1 . P h l$ isolates from soil planted with sorghum cultivar Redlan were detectable at the end cycle 4 (25.0\%; SD=35.4). Means across cycles of characteristics of Pseudomonas spp. during cycling are listed in Table 1.

When seedlings were grown in soils previously cycled with seedlings of wheat cultivar Lewjain or sorghum genotypes Redlan or RTx433, there appeared to be differences in characteristics of soilassociated fluorescent Pseudomonas spp. attributable to previous crop. Increased percentages of proteaseproducing isolates were found when Redlan seedlings were cycled in Redlan soils, or when Lewjain or RTx433 seedlings were planted in soil previously cycled with Lewjain (Table 1). Overall, the percent of isolates with $\mathrm{HCN}$ production appeared to increase during cycles 5 through $8(P=0.08)$. There appeared to be an increase in percent of $\mathrm{HCN}$-producing Pseudomonas spp. isolates associated with Lewjain seedlings planted in Lewjain soil when compared with those associated with Lewjain planted into soils previously cycled with sorghum (Table 1). Overall, the percentage of isolates with $P h l$ appeared to decline from cycle $5(39.3 \% ; \mathrm{SD}=44.1)$ to cycle $8(6.5 \%$; $\mathrm{SD}=15.4 ; P=0.07)$. However, there appeared to be an 
a Culturable fungi and Oomycetes

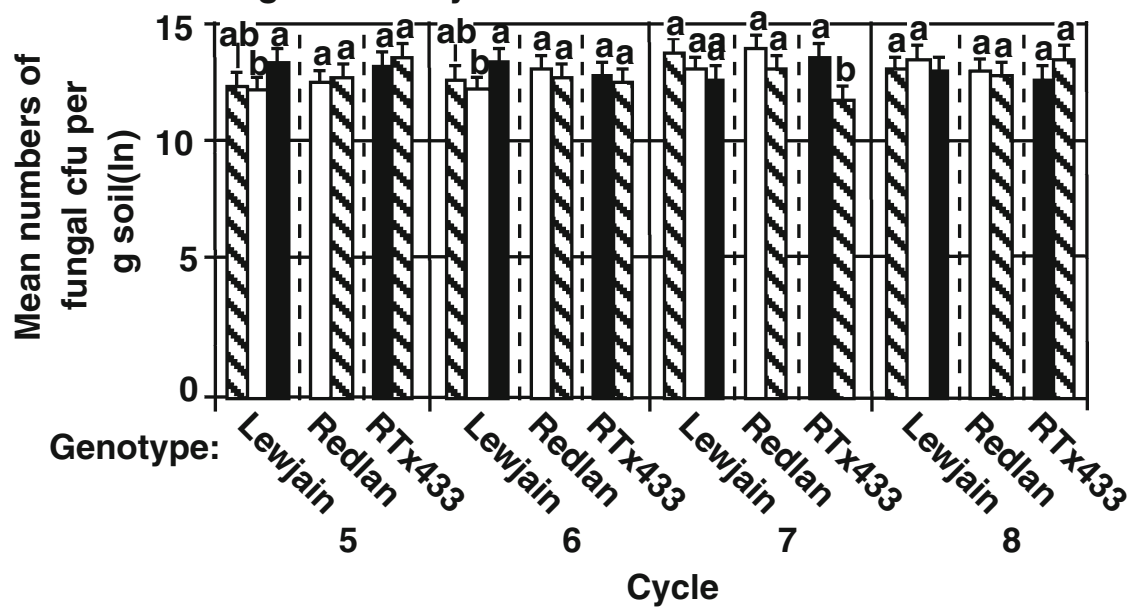

b Fluorescent Pseudomonas spp.

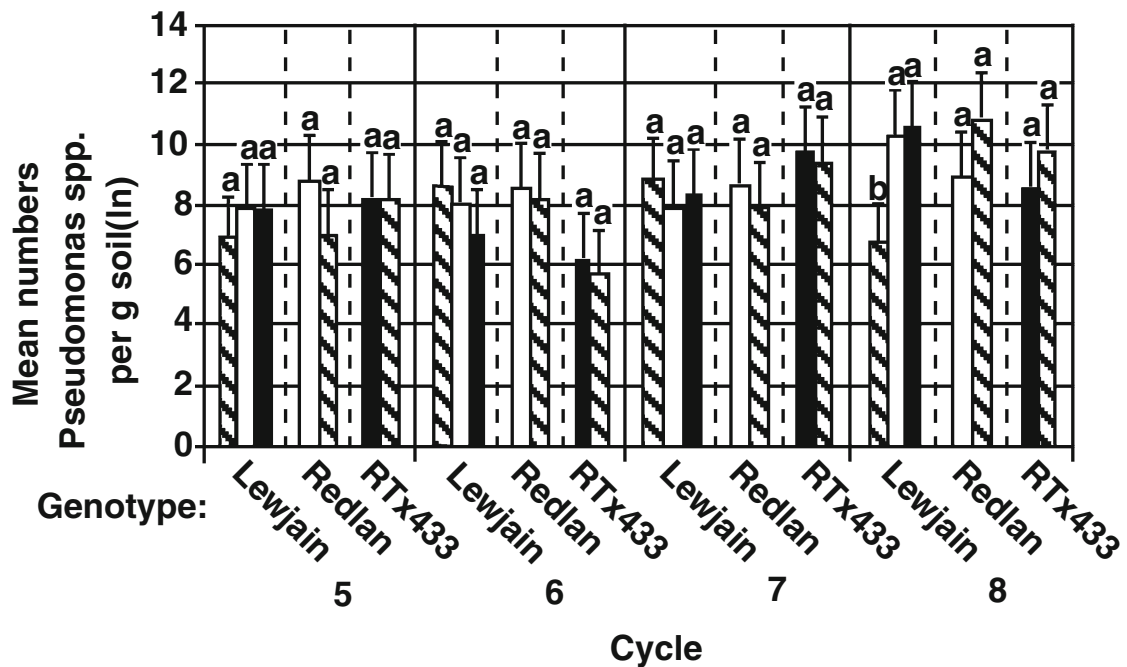

\section{Soil: $\square$ Le wjain $\square$ Redlan $\square$ RTx433}

Fig. 3 Ln of mean numbers of cfu per gram soil of culturable fungi and oomycetes (a) or fluorescent Pseudomonas spp. (b) at end of each cycle in soils previously planted with seedlings of wheat cultivar Lewjain and sorghum genotypes Redlan and RTx433. Results from cycles are separated by solid vertical lines; treatments compared within each cycle are separated by dashed vertical lines. Within each set of treatments the first bar

increase in percent of $\mathrm{Phl}$ producers associated with Redlan planted into soil previously cycled with Redlan seedlings. In contrast, percent of Phl producers associated with soil planted with Redlan seedlings, cycled in Lewjain soil, appeared to be depressed when compared with most other treatments (Table 1). represents the given genotype planted in soil previously planted with the same genotype, and the second or third bar represents that genotype planted in soil previously planted with the other species. Positive SEs are shown. Significant differences between treatments within cycles and plant genotype are indicated with letters; the same letter indicates no significant differences between treatments

Survival of rifampicin-marked Phl-producing $P$. fluorescens in root and soil associated with seedlings of two sorghum genotypes, as compared with wheat seedlings

Two assays for each rifampicin marked isolate, Q2-87R $\mathrm{R}^{+}$ and Q8r1-96R ${ }^{+}$, were conducted. In general it was found 
Table 1 Fluorescent Pseudomonas spp. obtained from field soil and during cycling in field soil and cycling in previously cropped soil were screened for four characteristics: hydrogen cyanide $(\mathrm{HCN})$ production, protease activity, and the presence of genes for antibiotic production $(P h l$ and $P C A)$

\begin{tabular}{|c|c|c|c|c|c|}
\hline \multirow[t]{2}{*}{ Plant genotype ${ }^{a}$} & \multirow[t]{2}{*}{ Previous crop ${ }^{b}$} & \multicolumn{4}{|c|}{ Percent of isolates with anti-microbial activity ${ }^{c}$} \\
\hline & & $\mathrm{HCN}$ & Protease & $P h l$ & $P C A$ \\
\hline \multicolumn{6}{|l|}{ Field soil } \\
\hline Unplanted & None & $0.0 \pm 0.0$ & $57.2 \pm 60.6$ & $0.0 \pm 0.0$ & $0.0 \pm 0.0$ \\
\hline \multicolumn{6}{|c|}{ Seedling cycling (cycles 1 through 4 ) } \\
\hline Lewjain & None & $4.4 \pm 7.3$ & $50.8 \pm 46.8$ & $26.5 \pm 44.2$ & $0.0 \pm 0.0$ \\
\hline Redlan & None & $6.3 \pm 17.7$ & $52.7 \pm 46.1$ & $6.3 \pm 17.7$ & $0.0 \pm 0.0$ \\
\hline $\mathrm{RT} 4333$ & None & $7.5 \pm 14.2$ & $59.6 \pm 44.3$ & $14.8 \pm 35.0$ & $0.0 \pm 0.0$ \\
\hline \multicolumn{6}{|c|}{ Seedling cycling in previously planted soil (cycles 5 through 8 ) } \\
\hline Lewjain & Lewjain & $36.4 \pm 38.1$ & $78.9 \pm 37.4$ & $22.0 \pm 38.3$ & $0.0 \pm 0.0$ \\
\hline Lewjain & Redlan & $9.1 \pm 12.5$ & $59.3 \pm 37.1$ & $28.7 \pm 40.4$ & $0.0 \pm 0.0$ \\
\hline Lewjain & $\mathrm{RTx} 433$ & $7.6 \pm 11.3$ & $55.5 \pm 40.8$ & $35.4 \pm 40.8$ & $0.0 \pm 0.0$ \\
\hline Redlan & Redlan & $16.1 \pm 22.1$ & $84.4 \pm 17.9$ & $54.8 \pm 42.2$ & $0.0 \pm 0.0$ \\
\hline Redlan & Lewjain & $15.2 \pm 35.1$ & $54.7 \pm 37.7$ & $15.5 \pm 35.2$ & $0.0 \pm 0.0$ \\
\hline RTx433 & RTx433 & $10.3 \pm 16.3$ & $48.2 \pm 38.8$ & $33.4 \pm 42.6$ & $2.3 \pm 6.4$ \\
\hline RTx433 & Lewjain & $20.2 \pm 36.6$ & $67.6 \pm 33.7$ & $38.9 \pm 46.4$ & $0.0 \pm 0.0$ \\
\hline
\end{tabular}

a "Unplanted" indicates isolates obtained from field soil prior to cycling experiment. Lewjain is a wheat cultivar and Redlan and RTx433 are sorghum genotypes.

b "None" indicates soil was obtained from sorghum field (see "Materials and methods"). "Lewjain," "Redlan" or "RTx433" indicates genotype of seedlings previously cycled in soil.

${ }^{\mathrm{c}}$ Means and SDs are reported.

that, despite gradual declines in rifampicin-resistant Pseudomonas spp. in rhizosphere and soil, marked strains associated with sorghum seedlings survived at similar levels and for at least as long as those associated with wheat seedlings under controlled conditions.

Assays conducted by applying Q2-87 $\mathrm{R}^{+}$to soil were 5 weeks (first assay) or 7 weeks (second assay) in duration. For both assays, numbers of rifampicinresistant fluorescent pseudomonads per gram roots were statistically significant for time point and for time point $\times$ genotype interactions $(P<0.01)$ and, in the second assay, for genotype $(P=0.01)$. With regard to soil, numbers of rifampicin-resistant fluorescent pseudomonads were statistically significant for time-point and for genotype for both assays $(P<0.01)$. Mean colonization, over all time points, of roots of sorghum cultivar Redlan was statistically significantly greater than colonization of sorghum genotype RTx433 in both assays $(P \leq 0.01)$ and colonization of sorghum soil by rifampicin resistant pseudomonads was significantly greater than that of wheat cultivar Lewjain (Table 2).

For both assays using Q8r1-96 ${ }^{+}$, cfu of rifampicin resistant fluorescent pseudomonads per gram roots were statistically significant for time point $(P<0.01)$ and time point $\times$ genotype interactions $(P=0.02$ for the first assay and $P<0.01$ for the second assay), and genotype was significant for the second assay $(P<$ 0.01). Numbers of rifampicin resistant fluorescent Pseudomonas spp. per gram soil were statistically significant for time point, genotype and time point $\times$ genotype interactions for both assays $(P<0.01)$. Mean colonization of soil associated with both sorghum genotypes, across all time points, was significantly greater than colonization of conetainer soils planted with wheat for both assays (Table 2).

In summary, when seedlings of either Redlan or RTx433 were cycled prior to planting of seedlings of wheat cultivar Lewjain, numbers of culturable fungi and oomycetes associated with Lewjain were statistically significantly different, depending upon the previously planted sorghum genotype. Additionally, numbers of fluorescent Pseudomonas spp. were statistically significantly higher when Lewjain was planted in soil previously planted with either sorghum genotype, as compared with those associated with Lewjain planted in Lewjain soil. When comparing four characteristics of fluorescent Pseudomonas spp. associated with wheat or sorghum seedlings planted in 
Table 2 Mean colonization ( $\mathrm{cfu} \mathrm{g}^{-1}$ ) of root tissue or soil planted with wheat cultivar Lewjain or sorghum genotypes Redlan or RTx433 with rifampicin-marked strains of $P$. fluorescens

\begin{tabular}{|c|c|c|c|c|}
\hline \multirow[t]{2}{*}{ Plant genotype } & \multicolumn{2}{|l|}{ First assay } & \multicolumn{2}{|l|}{ Second assay } \\
\hline & Root & Soil & Root & Soil \\
\hline \multicolumn{5}{|c|}{ Innoculant: Q2-87R ${ }^{+}$} \\
\hline Lewjain & $2.73 \times 10^{7} \mathrm{ab}^{\mathrm{a}} \pm 4.60 \times 10^{6}$ & $1.92 \times 10^{6} \mathrm{~b} \pm 2.87 \times 10^{5}$ & $7.08 \times 10^{6} \mathrm{~b} \pm 1.01 \times 10^{6}$ & $8.09 \times 10^{5} \mathrm{c} \pm 9.88 \times 10^{4}$ \\
\hline Redlan & $5.16 \times 10^{7} \mathrm{a} \pm 7.84 \times 10^{6}$ & $6.68 \times 10^{6} \mathrm{a} \pm 1.04 \times 10^{6}$ & $1.98 \times 10^{7} \mathrm{a} \pm 2.74 \times 10^{6}$ & $2.01 \times 10^{6} \mathrm{a} \pm 2.39 \times 10^{5}$ \\
\hline RTx433 & $2.26 \times 10^{7} b \pm 3.50 \times 10^{6}$ & $9.79 \times 10^{6} \mathrm{a} \pm 1.46 \times 10^{6}$ & $8.41 \times 10^{6} \mathrm{~b} \pm 1.20 \times 10^{6}$ & $1.66 \times 10^{6} \mathrm{~b} \pm 2.03 \times 10^{5}$ \\
\hline \multicolumn{5}{|c|}{ Innoculant: Q8r1-96R ${ }^{+}$} \\
\hline Lewjain & $6.85 \times 10^{6} \mathrm{ab} \pm 8.16 \times 10^{5}$ & $4.27 \times 10^{5} \mathrm{~b} \pm 6.03 \times 10^{4}$ & $2.46 \times 10^{7} \mathrm{c} \pm 2.71 \times 10^{6}$ & $7.69 \times 10^{6} \mathrm{c} \pm 9.76 \times 10^{5}$ \\
\hline Redlan & $1.08 \times 10^{7} \mathrm{a} \pm 1.51 \times 10^{6}$ & $7.80 \times 10^{5} \mathrm{a} \pm 1.49 \times 10^{5}$ & $4.06 \times 10^{7} \mathrm{~b} \pm 4.57 \times 10^{6}$ & $2.82 \times 10^{7} b \pm 3.46 \times 10^{6}$ \\
\hline $\mathrm{RTx} 433$ & $8.71 \times 10^{6} b \pm 1.10 \times 10^{6}$ & $1.22 \times 10^{6} \mathrm{a} \pm 1.75 \times 10^{5}$ & $1.02 \times 10^{8} \mathrm{a} \pm 1.11 \times 10^{7}$ & $5.55 \times 10^{7} \mathrm{a} \pm 6.71 \times 10^{6}$ \\
\hline
\end{tabular}

${ }^{a}$ When comparing plant genotypes within a column, means with different letters are significantly different. Standard deviations are reported.

soils previously planted with either wheat or sorghum, there appeared to be and overall increase in the percent of isolates producing $\mathrm{HCN}$ during cycling. Also there appeared to be a greater percentage of isolates carrying the locus for PhlD when sorghum cultivar Redlan was planted into Redlan soil, as compared with isolates associated with Redlan planted into soil previously cropped with wheat cultivar Lewjain.

\section{Discussion}

The present study focused on effects of seedlings of two grain-sorghum genotypes on plant growth and on populations of soil microorganisms as a result of cycling, as compared with the more well-studied grain crop, wheat. Growth during short planting cycles (4 weeks) of seedlings of two sorghum genotypes and a wheat cultivar was determined. Additionally, numbers of culturable bacteria, fungi and oomycetes, and fluorescent Pseudomonas spp. were monitored. A subset of fluorescent Pseudomonas spp. was tested for production of extracellular proteases and $\mathrm{HCN}$ and for the presence of two genes for antibiotic production. Between cycles, root residues were left in soil to mimic conservation tillage practices (Gebhardt et al. 1985) which may increase pathogen loads (Cook and Haglund 1991). To determine effects of previous crop, soil previously cycled with wheat seedlings were planted with sorghum and soils planted with each sorghum genotype were planted with wheat. Plant growth, numbers of microorganisms and phenotypes of fluorescent Pseudomonas spp. were again monitored during cycling. The capacity of seedling roots from the two sorghum genotypes to support growth of two wellcharacterized Pseudomonas fluorescens wheat isolates (Raaijmakers and Weller 2001), as compared with wheat cultivar Lewjain, also was assessed.

Some soil microorganisms, particularly fungi, can cause seed decay, damping-off and root rots of sorghum seedlings (Forbes and Odvody 2000). On the other hand, beneficial microorganisms, fungi and bacteria, could provide protection (Hameeda et al. 2007). Therefore, examination of how different sorghum genotypes can modify populations of fungi and oomycetes, and bacteria may provide understanding of a mechanism of protection for young sorghum plants. Sorghum can be used in rotations, as a cover crop or as a preplant treatment because of its potentially negative impacts on weeds (reviewed in Anaya 1999) and plant parasitic fungi (Singh et al. 1990) and nematodes (Rupe et al. 1997). Cycling may be a way to enhance these effects (Raaijmakers and Weller 2001; Mazzola and Gu 2002; Mazzola et al. 2004). In the present study, an examination of phenotypes and genotypes of fluorescent Pseudomonas spp. was conducted to assess changes in soil populations during cycling. Fluorescent pseudomonads have been associated with biological control of diseases of plants, particularly those caused by fungi but also those incited by other bacteria ( $\mathrm{Ji}$ et al. 2006; Picard and Bosco 2008). Although generally associated with biological control, these bacteria also may be involved in plant diseases (Belimov et al. 2007).

Previous field studies have provided evidence that sorghum could inhibit growth of weeds or of 
subsequent crops (Roth et al. 1999; Iqbal et al. 2007). Phytotoxic compounds in sorghum stalks and leaves, such as phenolics or cyanogenic glucosides, may have contributed to this allelopathic effect (Halkier and Møller 1989; Sène et al. 2001). In the present study, growth chamber assays were used to determine whether cycling of sorghum seedlings or cycling of wheat in soil previously cropped with sorghum genotypes would effect seedling growth. Stalks and leaves were removed, and roots incorporated into the soil, to assess affects of roots and root exudates on following plantings. Redlan and RTx433 were chosen for this study as laboratory studies had shown that the two genotypes produced significantly different amounts of the allelopathic compound sorgoleone (Nimbal et al. 1996). In spite of previous reports of toxic effects of sorgoleone on seedlings of various crops during in vitro studies (Rasmussen et al. 1992), no significant effect of cycling in field soil, or in previously cropped soil, on wet weight of sorghum and wheat seedlings, was observed in the present study.

No previous studies are known of monitoring soil populations of microorganisms during cycling of sorghum. Field studies of sorghum in rotation cropping systems have indicated that planting of sorghum can modify numbers of pathogenic and beneficial fungi (Singh et al. 1990; Ellis et al. 1992;). It is recognized that cultural techniques are only able to assess a small portion of total microbial populations and simply changing the environment (e.g. from soil to culture medium) can modify the population structure of culturable microorganisms (Staley and Konopka 1985; Dunbar et al. 1997). Nonetheless, in the present study, differences in populations of microorganisms associated with the two sorghum genotypes were observed. Mean numbers of total culturable fungal and oomycete cfu were significantly greater in soils planted with sorghum genotype RTx433 than in soils planted with sorghum cultivar Redlan (Fig. 2a). Similarly, numbers of fluorescent Pseudomonas spp. were significantly greater in soils planted with RTx433 than those planted with Redlan (Fig. 2b). To our knowledge, this is the first report of differences between sorghum genotypes, with regard to associations with soil microorganisms.

Statistical significance was demonstrated regarding numbers of culturable bacteria (previous-crop experiment), of fungi and oomycetes (both experiments) and fluorescent Pseudomonas spp. (both experiments) in these relatively insensitive assessments of soil microbial populations. However, in only one case were the means greater than ten fold different: the numbers ( $\mathrm{cfu} \mathrm{g}^{-1}$ ) of fluorescent Pseudomonas spp. in wheat grown in soil previously planted with RTx433 $\left(3.35 \times 10^{5} ; \mathrm{SE}=2.06 \times 10^{5}\right)$ versus wheat grown in wheat soil $\left(1.72 \times 10^{4} ; \mathrm{SE}=1.10 \times 10^{4}\right.$; Fig. $\left.3 \mathrm{~b}\right)$. In other cases in which statistical significance were demonstrated, differences were approximately twofold. It is generally and reasonably believed that for changes in microorganism populations to be biologically significant, differences in numbers need to be at least by a power of 10 (Curl and Truelove 1986; Briones et al. 2002). However, trends also have drawn notice (Gu and Mazzola 2003; McSpadden-Gardener 2007) and, especially in field studies, even statistical significance may have been difficult to demonstrate (Schwerinski et al. 2007). Additionally, relative totals may not demonstrate huge changes but may reflect changes in specific groups of organisms (Curl and Truelove 1986). It is not known whether subtle but statistically significant shifts in one or more factors would have at least minor impact on crops in the field (Degens et al. 2001; Garbeva et al. 2004). Nonetheless, small differences (less than 10-fold) should be biologically interpreted with caution.

Properties that may affect microbial populations associated with roots may include exudation of a variety of primary and secondary metabolites, including phenolic compounds, potentially toxic compounds, or nutrients (Bais et al. 2006), or physical properties of root architecture (Okubara et al. 2004). Although production of sorgoleone from roots of germinated seedlings has been shown to be higher from cultivar Redlan (approximately $18 \mathrm{mg} \mathrm{g}^{-1}$ root fresh weight) than in genotype RTx433 (less than $1 \mathrm{mg} \mathrm{g}^{-1}$ root fresh weight; Nimbal et al. 1996), no other properties of root exudates from these genotypes have been reported. In the present study, it was unknown the combination of traits involved in the observed differential colonization of soil planted with either Redlan or RTx433 by fungi and fluorescent Pseudomonas spp.

In these assays, previous crop appeared to affect population numbers of microorganisms. This was particularly evident when seedlings of wheat cultivar Lewjain were cycled in soils with different previous crops. Lewjain seedlings planted in Lewjain soil yielded significantly fewer numbers of fluorescent Pseudomonas spp. than when planted into soils 
previously planted with either sorghum genotype. Statistically significant differences in mean numbers of culturable soil fungi and oomycetes were evident when comparing Lewjain planted into soils previously planted with the two sorghum genotypes, particularly in cycles 5 and 6: numbers of soilassociated culturable fungi were greater when Lewjain seedlings were grown in RTx433 soil as compared with seedlings grown in Redlan soil (Fig. 2). The present work is the first known to provide evidence that sorghum genotypes may differentially affect numbers of microorganisms when preceding other crops.

Percentage of fluorescent Pseudomonas spp. with potential antibiotic activities was monitored through the two cycling experiments. HCN-producing isolates and isolates with $P h l$, not detectable in fallow or postharvest soil, were detected after one cycle planted with wheat and sorghum seedlings (Table 1). After cycling seedlings in previously cropped soils (cycles 5 through 8), two trends were noticed in the characteristics of populations of fluorescent Pseudomonas spp. Firstly, there appeared to be an overall increase in HCN producers (Table 1); although $\mathrm{HCN}$ may be involved in suppression of plant diseases (Laville et al. 1992), production by rhizobacteria also can have a detrimental effect on some plants (Bakker and Schippers 1987). Secondly, throughout the course of these cycling experiments, there appeared to be an overall decline in the number of $P h l$ isolates (Table 1), especially noticeable in cycles 5 through 8 . Changes in populations of Phl-producing strains during monoculture in the field (Cook 2007) and during greenhouse cycling (Raaijmakers and Weller 1998) have been well-documented. Raaijmakers and Weller (1998) reported that during nine successive 3-weeklong cycles, detection of Phl-producers in wheat rhizospheres, as indicated by colony hybridization with a portion of the PhlD gene, was highest after the fourth cycle, then declined somewhat, but was stable in later cycles. In the present study, percentage of fluorescent Pseudomonas spp. with $\mathrm{Phl}$ was variable, but was still high after cycle $6[50.0 \%( \pm 70.7)]$, then declined in cycle $7[23.1 \%( \pm 32.7)]$ and cycle $8[3.9 \%$ $( \pm 5.4)]$. It is not known whether this apparent decline is due to fluctuations and variability in the percentage of $P h l$ isolates throughout the assays, or if in further cycles, their numbers would continue to be low. Physical properties of the soil (Duffy and Défago
1999) or cropping history (Stark et al. 2007) may effect populations of Phl producers.

Rifampicin-marked P. fluorescens wheat isolates, Q2-87R ${ }^{+}$and Q8r1-96R ${ }^{+}$, were applied to soils that were then planted with wheat cultivar Lewjain and sorghum genotypes RTx433 and Redlan, to determine whether these potential biological control agents could be maintained on sorghum root surfaces and nearby soil. After application of large numbers (approximately $1 \times 10^{8} \mathrm{cfu}^{-1}$ soil) of $\mathrm{Q} 2-87 \mathrm{R}^{+}$or Q8r1-96 ${ }^{+}$to pasteurized soil, rifampicin-resistant fluorescent pseudomonad colonies appeared to be established in the rhizospheres of Redlan and RTx433 seedlings and to persist in conetainer soils at least as well as in the rhizospheres and soils of Lewjain seedlings through the length of these controlled experiments (Table 2). It has been previously demonstrated that Phl-producing Pseudomonas isolates from wheat, as well as from tobacco and tomato, were capable of providing biological control against rootinfections of cucumber and tomato (Rezzonico et al. 2007). In the present study, when considering mean cfu per gram root tissue across time points, there were significant differences between colonization by Q2$87 \mathrm{R}^{+}$(in both assays) and Q8r1-96R ${ }^{+}$(in one assay) in the rhizospheres of the different sorghum genotypes tested (Table 2), consistent with what has been observed in wheat (Okubara et al. 2004). These results provide further support to the hypothesis that sorghum genotypes may induce growth of rootassociated bacteria differentially.

Acknowledgements We thank M. Mazzola, L. Thomashow and the NCAUR for bacterial cultures and K. Garland-Campbell for wheat seed. We thank J. Toy for production and maintenance of sorghum grain, P. O'Neill for overseeing laboratory operations and for assistance with statistical analyses and T. Eisenhauer and M. Ebeling for technical assistance. We also thank K. P. Vogel for valuable editorial suggestions. Mention of trade names or commercial products in this article is solely for the purpose of providing specific information and does not imply recommendation or endorsement by the U.S. Department of Agriculture. This article is in the public domain and not copyrightable. It may be freely reprinted with customary crediting of source.

\section{References}

Anaya AL (1999) Allelopathy as a tool in the management of biotic resources in agroecosystems. Crit Rev Plant Sci 18:697-739

Andrade G, Linderman RG, Bethlenfalvay GJ (1998) Bacterial associations with the mycorrhizosphere and hyphosphere 
of the abuscular mycorrhizal fungus Glomus mosseae. Plant Soil 202:79-87

Bais HP, Weir TL, Perry LG, Gilroy S, Vivanco JM (2006) The role of root exudates in rhizosphere interactions with plants and other organisms. Annu Rev Plant Biol 57:233-266

Bakker AW, Schippers B (1987) Microbial cyanide production in the rhizosphere in relation to potato yield reduction and Pseudomonas spp-mediated plant growth-stimulation. Soil Biol Biochem 19:451-457

Bangera MG, Thomashow LS (1999) Identification and characterization of a gene cluster for synthesis of the polyketide antibiotic 2,4-diacetylphloroglucinol from $\mathrm{Pseu}$ domonas fluorescens Q2-87. J Bacteriol 181:3155-3163

Bano N, Musarrat J (2003) Characterization of a new Pseudomonas aeruginosa strain $\mathrm{NJ}-15$ as a potential biocontrol agent. Curr Microbiol 46:324-328

Belimov AA, Dodd IC, Safronova VI, Hontzeas N, Davies WJ (2007) Pseudomonas brassicacearum strain Am3 containing 1-aminocyclopropane-1-carboxylate deaminase can show both pathogenic and growth-promoting properties in its interaction with tomato. J Exp Bot 58:1485-1495

Belz RG (2007) Allelopathy in crop/weed interactions - an update. Pest Manag Sci 63:308-326

Berg G, Roskot N, Steidle A, Eberl L, Zock A, Smalla K (2002) Plant-dependent genotypic and phenotypic diversity of antagonistic rhizobacteria isolated from different Verticillium host plants. Appl Environ Microbiol 68:3328-3338

Bertin C, Yang X, Weston LA (2003) The role of root exudates and allelochemicals in the rhizosphere. Plant Soil 256:67-83

Briones AM, Okabe S, Umemiya Y, Ramsing N-B, Reichards W, Okuyama H (2002) Influence of different cultivars on populations of ammonia-oxidizing bacteria in the root environment of rice. Appl Environ Microbiol 68:3067-3075

Castric KF, Castric PA (1983) Method for rapid detection of cyanogenic bacteria. Appl Environ Microbiol 45:701-702

Chang M, Netzly DH, Butler LG, Lynn DG (1986) Chemical regulation of distance: characterization of the first natural host germination stimulant for Striga asiatica. J Am Chem Soc 108:7858-7860

Cook RJ (2007) Management of resident plant growthpromoting rhizobacteria with the cropping system: a review of experience in the US Pacific Northwest. Eur J Plant Pathol 119:255-264

Cook RJ, Haglund WA (1991) Wheat yield depression associated with conservation tillage caused by root pathogens in the soil not phytotoxins from the straw. Soil Biol Biochem 23:1125-1132

Cook RJ, Thomashow LS, Weller DM, Fujimoto D, Mazzola M, Bangera $G$ et al (1995) Molecular mechanisms of defense by rhizobacteria against root disease. Proc Natl Acad Sci U S A 92:4197-4201

Cowan ST (1974) Cowan and Steele's manual for the identification of medical bacteria. Cambridge University Press, London, p 238

Curl EA, Truelove B (1986) The rhizosphere. Springer, Berlin, p 288

Degens BP, Schipper LA, Sparling GP, Duncan LC (2001) Is the microbial community in a soil with reduced catabolic diversity less resistant to stress or disturbance? Soil Biol Biochem 33:1143-1153

Duffy BK, Défago G (1999) Environmental factors modulating antibiotic and siderophore biosynthesis by Pseudomonas fluorescens biocontrol strains. Appl Environ Microbiol 65:2429-2438

Duffy B, Keel C, Défago G (2004) Potential role of pathogen signaling in multitrophic plant-microbe interactions involved in disease protection. Appl Environ Microbiol 70:1836-1842

Dunbar J, White S, Forney L (1997) Genetic diversity through the looking glass: effect of enrichment bias. Appl Environ Microbiol 63:1326-1331

Ellis JR, Roder W, Mason SC (1992) Grain sorghum-soybean rotation and fertilization influence on vesicular-arbuscular mycorrhizal fungi. Soil Sci Soc Am J 56:789-794

Fageria NK, Stone LF (2006) Physical, chemical and biological changes in the rhizosphere and nutrient availability. J Plant Nutr 29:1327-1356

Forbes GA, Odvody GN (2000) Seedling diseases. In: Richardson RA, Odvody GN (eds) Compendium of sorghum diseases. APS, St. Paul, MN, USA, pp 8-9

Garbeva P, van Veen JA, van Elsas JD (2004) Microbial diversity in soil: selection of microbial populations by plant and soil type and implications for disease suppressiveness. Annu Rev Phytopathol 42:243-270

Gebhardt MR, Daniel TC, Schweizer EE, Allmaras RR (1985) Conservation tillage. Science 230:625-630

Gu Y-H, Mazzola M (2003) Modification of fluorescent pseudomonad community and control of apple replant disease induces in a wheat cultivar-specific manner. Appl Soil Ecol 24:57-72

Halkier BA, Møller BL (1989) Biosynthesis of the cyanogenic glucoside dhurrin in seedlings of Sorghum bicolor (L.) Moench and partial purification of the enzyme system involved. Plant Physiol 90:1552-1559

Hameeda B, Srijana M, Rupela OP, Reddy G (2007) Effect of bacteria isolated from composts and macroflora on sorghum growth and mycorrhizal colonization. World J Microbiol Biotechnol 23:883-887

Iqbal J, Cheema ZA, An M (2007) Intercropping of field crops in cotton for the management of purple nutsedge (Cyperus rotundus L.). Plant Soil 300:163-171

Ji P, Campbell HL, Kloeper JW, Jones JB, Suslow TV, Wilson M (2006) Integrated biological control of bacterial speck and spot of tomato under field conditions using foliar biological control agents and plant growth-promoting rhizobacteria. Biol Control 36:358-367

Laville J, Voisard C, Keel C, Maurhofer M, Défago G, Haas D (1992) Global control in Pseudomonas fluorescens mediating antibiotic synthesis and suppression of black root rot of tobacco. Proc Natl Acad Sci U S A 89:1562-1566

Loper JE, Kobayashi DY, Paulsen IT (2007) The genomic sequence of Pseudomonas fluorescens PF-5: insights into biological control. Phytopathology 97:233-238

Mavrodi DV, Ksenzendo VN, Bonsall RF, Cook RJ, Bornin AM, Thomashow LS (1998) A seven gene locus for synthesis of phenazine-1-carboxylic acid by Pseudomonas fluorescens 2-79. J Bacteriol 180:2541-2548

Mazzola M, Gu Y-H (2000) Impact of wheat cultivation on microbial communities from replant soils and apple growth in greenhouse trials. Phytopathology 90:114-119

Mazzola M, Gu Y-H (2002) Wheat genotype-specific induction of soil microbial communities suppressive to disease incited by Rhizoctonia solani anastomosis group (AG)-5 and AG-8. Phytopathology 92:1300-1307 
Mazzola M, Fujimoto DK, Thomashow LS, Cook RJ (1995) Variation in sensitivity of Gaeumannomyces graminis to antibiotics produced by fluorescent Pseudomonas spp. and effect on biological control of take-all of wheat. Appl Environ Microbiol 61:2554-2559

Mazzola M, Funnell DL, Raaijmakers JM (2004) Wheat cultivar-specific selection of 2,4-diacetylphloroglucinolproducing fluorescent Pseudomonas species from resident soil populations. Microb Ecol 48:338-348

McSpadden-Gardener BB (2007) Diversity and ecology of biocontrol Pseudomonas spp. in agricultural systems. Phytopathology 97:221-226

Mercado-Blanco J, Bakker PAHM (2007) Interactions between plants and beneficial Pseudomonas spp.: exploiting bacterial traits for crop protection. Antonie Van Leeuwenhoek 92:367-389

Nimbal CI, Pedersen JF, Yerkes CN, Weston LA, Weller SC (1996) Phytotoxicity and distribution of sorgoleone in grain sorghum germplasm. J Agric Food Chem 44:1343-1347

Okubara PA, Kornoely JP, Landa BB (2004) Rhizosphere colonization of hexaploid wheat by Pseudomonas fluorescens strains Q8r1-96 and Q2-87 is cultivar-variable and associated with changes in gross root morphology. Biol Control 30:392-403

Picard C, Bosco M (2008) Genotypic and phenotypic diversity in populations of plant-probiotic Pseudomonas spp. colonizing roots. Naturwissenschaften 95:1-16

Raaijmakers JM, Weller DM (1998) Natural plant protection by 2,4-diacetylphloroglucinol-producing Pseudomonas spp. in take-all decline soils. Mol Plant Microbe Interact 11:144-152

Raaijmakers JM, Weller DM (2001) Exploiting genotypic diversity of 2,4-diacetylphloroglucinol-producing Pseudomonas spp.: characterization of superior root-colonizing $P$. fluorescens strain Q8r1-96. Appl Environ Microbiol 67:2545-2554

Raaijmakers JM, Weller DM, Thomashow LS (1997) Frequency of antibiotic-producing Pseudomonas spp. in natural environments. Appl Environ Microbiol 63:881-887

Rasmussen JA, Hejl AM, Einhellig FA, Thomas JA (1992) Sorgoleone from root exudates inhibits mitochondrial functions. J Chem Ecol 18:197-207

Rezzonico F, Zala M, Keel C, Duffy B, Moënne-Loccoz Y, Défago $G$ (2007) Is the ability of biocontrol fluorescent pseudomonads to produce the antifungal metabolite 2,4- diacetylphloroglucinol really synonymous with higher plant protection. New Phytol 173:861-872

Roth CM, Shroyer JP, Paulsen GM (1999) Allelopathy of sorghum on wheat under several tillage systems. Agron J 92:855-860

Rupe JC, Robbins RT, Gbur EE Jr (1997) Effect of crop rotation on soil population densities of Fusarium solani and Heterodera glycines and on the development of sudden death syndrome of soybean. Crop Prot 16:575-580

SAS (2000-2004) SAS 9.1.3 help and documentation. SAS Institute Inc., Cary, $\mathrm{NC}$

Schlegel AJ, Dumler TJ, Thompson CR (2002) Feasibility of four-year crop rotations in the Central High Plains. Agron J 94:509-517

Schwerinski K, Wolf A, Berg G (2007) Assessing the risk of biological control agents on the indigenous microbial communities: Serratia plymuthica HRO-C48 and Streptomyces sp. HRO-71 as model bacteria. BioControl 52:87-112

Sène M, Doré T, Gallet C (2001) Relationships between biomass and phenolic production in grain sorghum grown under different conditions. Agron J 93:49-54

Simon A, Ridge EH (1974) The use of ampicillin in a simplified selective medium for the isolation of fluorescent psuedomonads. J Appl Bacteriol 37:459-460

Singh SK, Nene YL, Reddy MV (1990) Influence of cropping systems on Macrophomina phaseolina populations in soil. Plant Dis 74:812-814

Staley JT, Konopka A (1985) Measurement of in situ activities of nonphotosynthetic microorganisms in aquatic and terrestrial habitats. Annu Rev Microbiol 39:321-346

Stark C, Condron LM, Stewart A, Di HJ, O'Callaghan M (2007) Effects of past and current crop management on soil microbial biomass and activity. Biol Fertil Soils 43:531-540

Weiland G, Neumann R, Backhaus H (2001) Variation of microbial communities in soil, rhizosphere, and rhizoplane in response to crop species, soil type and crop development. Appl Environ Microbiol 67:5849-5854

Wu H, Haig T, Pratley J, Lemerle D, An M (2001) Allelochemicals in wheat (Triticum aestivum L.): cultivar difference in the exudation of phenolic acids. J Agric Food Chem 49:3742-3745

Wu H, Pratley J, Lemerle D, An M, Liu DL (2007) Autotoxicity of wheat (Triticum aestivum L.) as determined by laboratory bioassays. Plant Soil 296:85-93 